Artigo original

Hegemonia - Revista Eletrônica de Relações Internacionais do Centro Universitário Unieuro

ISSN: $1809-1261$

UNIEURO, Brasília, número 21, Julho-Dezembro de 2017, pp. 82-106.

Recebido em: 22/3/2017

Avaliado em 12/4/2017

Aprovado em: 10/5/2017

\title{
A Industrialização Brasileira entre 1900 e 1930 em uma perspectiva histórica
}

George Henrique de Moura Cunha, ${ }^{1}$ Matheus Silva de Paiva, ${ }^{2}$ Michel Constantino, ${ }^{3}$ e Micaele Miguel do Nascimento Lustosa ${ }^{4}$

RESUMO: Nas primeiras décadas do século XX, o Brasil passou por diversas transformações e seguia em busca do seu desenvolvimento industrial. A partir de alterações importantes em sua estrutura, constituía-se o desenvolvimento, estimulado por diversas transformações na sociedade, como o fim da colonização, da escravidão, a expansão da agricultura e das exportações dos produtos primários, também com a formação de imigrantes e entrada de capital estrangeiro. A análise do período histórico das estruturas política e econômica brasileira durante a República associou-se à vulnerabilidade da economia primário-exportadora e à substituição das importações de produtos industrializados. O período que antecedeu a crise de 1930 caracterizou-se, de forma não muito semelhantemente aos países de primeiro mundo, que já viviam essa transformação, por uma importação de mão-de-obra especializada e de uma cultura tipicamente constituída de produtivos de bens de consumos básicos. Palavras-Chave: Desenvolvimento Industrial, Colonização, Importações, Capital Estrangeiro.

ABSTRACT: In the first decades of the twentieth century, Brazil underwent several transformations and continued its search for industrial development. As a result of important changes in its structure, it was development, stimulated by various changes in society, such as the end of colonization, slavery, expansion of agriculture and exports of primary products, also with the formation of immigrants and entry of foreign capital. The analysis of the historical period of Brazilian political and economic structures during the Republic was associated with the vulnerability of the primary export economy and the substitution of imports of industrialized products. The period leading up to the crisis of the 1930s was characterized not so much by the first world countries that were already experiencing this transformation, by the importation of skilled labor and by a culture typically constituted of productive consumption goods.

Keywords: Industrial Development, Colonization, Imports, Foreign Capital.

\footnotetext{
${ }^{1}$ Professor da Universidade Católica de Brasília (UCB).

2 Professor da Universidade Católica de Brasília (UCB) e Doutorando em Economia pela Universidade de Brasília (UnB).

${ }^{3}$ Professor da Universidade Católica Don Bosco (UCDB).

${ }^{4}$ Bacharel em Economia pela Universidade Católica de Brasília.
} 
Artigo original

Hegemonia - Revista Eletrônica de Relações Internacionais do Centro Universitário Unieuro

ISSN: 1809-1261

UNIEURO, Brasília, número 21, Julho-Dezembro de 2017, pp. 82-106.

\section{Introdução}

O panorama geral da indústria brasileira da década de 1930 revela aspectos importantes, período onde ela deu um significativo salto em importância na história econômica brasileira. Entender esse quadro, portanto, ajuda na compreensão do processo produtivo industrial brasileiro. Dentro dessa análise contextual, um dos temas mais relevantes é o rápido desenvolvimento industrial brasileiro, que se tornou significativo a partir das últimas décadas do século XIX. A partir disso, Lewis (2001, p. 116) teoriza que "por indústria se entende um processo que tenha como base a fábrica e utilizava técnicas que não estavam muito distantes daquelas empregadas em outras economias industrializadas”.

Em relação à conjuntura da época, a economia brasileira, desde o Período Colonial (15001822), valeu-se de sua deliberada política mercantilista portuguesa fechada, destinando suas mercadorias somente à metrópole, de modo que havia barreiras à indústria nacional, de modo a fazer com que os brasileiros consumissem somente os produtos portugueses. Dentro dessa análise contextual, conforme essas restrições, o processo industrial prosseguiu durante o Império Brasileiro (1822-1889). A partir disso, Baer (1988) destaca que economia do país já dependia das exportações dos produtos de natureza primária, formando assim o modelo primário-exportador, que influenciou e deu ritmo ao crescimento econômico, baseado no desenvolvimento industrial e em fatores potenciais, como a forte imigração europeia, a política de portas abertas e as diversas mudanças sociais.

O desenvolvimento industrial brasileiro, conforme Lewis (2001, p. 114), caracterizou-se por três períodos distintos, quais sejam, i) as décadas que se seguiram à independência (1822), com a manufatura colonial e fins de 1890; ii) a expansão das exportações com o mercado de bens de consumo e bens de capitais nos anos da Primeira Guerra Mundial; e iii) período que cobre os anos da crise no café até a Depressão com escalas na indústria.

Durante a República Velha, encontra-se em São Paulo a produção de café, precisamente o produto mais dinâmico da economia brasileira, como base juntamente para as exportações, enquanto que as importações eram consideradas como um obstáculo ao desenvolvimento industrial. Conforme Baer (1988) enfatiza, o principal influenciador da industrialização era pressionado pela dependência da demanda nacional por bens de capitais (equipamentos) que, anteriormente, o país não produzia.

Nesse período, o país passava por uma série de transformações e começava a participar de uma revolução industrial, trocando seus produtos extrativos e agrícolas por artigos manufaturados. 
Artigo original

Hegemonia - Revista Eletrônica de Relações Internacionais do Centro Universitário Unieuro

ISSN: 1809-1261

UNIEURO, Brasília, número 21, Julho-Dezembro de 2017, pp. 82-106.

Nesse sentido, Baer (1988) afirma que houve favoráveis fatores que poderiam ocasionar a aceleração do desenvolvimento industrial, tais como: i) a própria implantação dos investimentos estrangeiros; ii) a utilização das ferrovias e dos portos anteriormente utilizados na agricultura; iii) o rápido crescimento dos centros urbanos; iv) a imigração de mão-de-obra estrangeira especializada e; v) o Estado, ao realizar investimentos em infraestrutura e baixa de taxas.

Dean (2002) observa que, durante a Primeira Guerra Mundial, houve um superávit comercial, isso corrobora com a ideia de que os períodos de crise foram relativamente favoráveis para o crescimento industrial. A Primeira Guerra Mundial (1914-1918), a Crise Econômica Mundial, a Queda da Bolsa de Nova Iorque em 1929 e a depressão dos anos 30, produziram efeitos sobre os investimentos nacionais e as importações brasileiras, pois substancialmente nesses períodos o comércio das importações entrava em declínio.

Dean (2002, p. 659) relata que "o nível de investimentos ingleses e norte-americanos cresceu, passando de 53 milhões de libras em 1880 para 385 milhões em 1929”, pois os países envolvidos na guerra estavam com suas indústrias arrasadas. Porém, apesar de fatores positivos para a aceleração industrial, o desfecho ocasionou um lento crescimento da produção industrial, pois os países já estavam bem avançados.

O que caracterizou a economia antes de 1900 foi, basicamente, a expansão do comércio exterior. Por sua vez, as exportações atraíram o capital estrangeiro, e consequentemente desencadeou um crescimento econômico. Segundo Haddad (1975, apud Dean 2002, p. 659), o PIB per capita, "no período de 1900 a 1929, cresceu a uma taxa média de quase 2,5 por cento ao ano". Vale ressaltar como fator importante, que o crescimento industrial dependia da mudança nas estruturas econômicas, sociais e institucionais, que não se formavam na mesma na proporção que o crescimento populacional. Isso não ocorria devido a carência de uma indústria de base, pela escassez e os altos custos dos insumos, ao lado da alta dos impostos e uma relevada hostilidade do governo ao empresário, também com as margens de lucro dos industriais reduzidas.

Sendo assim, as empresas nacionais tiveram dificuldade para expandir suas capacidades na mesma proporção das novas técnicas dos países desenvolvidos e ampliar em um mercado nacional. Logo, formava-se uma indústria de bens de consumo. A indústria pesada foi mais demorada, e só veio a surgir na virada do século, pois essa indústria de transformação dependia fortemente de insumos importados como as máquinas e matéria-prima. 
Artigo original

Hegemonia - Revista Eletrônica de Relações Internacionais do Centro Universitário Unieuro

ISSN: $1809-1261$

UNIEURO, Brasília, número 21, Julho-Dezembro de 2017, pp. 82-106.

2. O modelo brasileiro primário-exportador

O Brasil exportava mercadorias primárias aos países industrializados e, face à concorrência externa, formava a economia primária exportadora. As importações brasileiras consistiam nas matérias-primas e nos artigos manufaturados, vindas da metrópole e da Inglaterra, o que tornava extremamente difícil o estabelecimento de indústrias no país. O modelo primário-exportador deste período foi acompanhado por uma política agrária do final do século XIX e início do século XX, caracterizando-se pela manufatura colonial de mão-de-obra escrava e compondo o cultivo de produtos primários. O que mais singulariza o período foi o auge do crescimento do nível de investimentos desses estrangeiros que se sentiam atraídos pelo sucesso das exportações e a formação de capital.

Conforme Lewis (2001, p. 129), a produção de bens primários estava associada a um aumento dos lucros internos, à entrada de capital estrangeiro e a elevação da demanda de bens de consumo, causado pelo crescimento da população e impulsionado com a imigração e a consolidação de uma economia salarial. A extensão da fronteira agrícola e as exportações ocorriam com sucesso, pois, conforme Dean atesta (2002, p. 665), “os ciclos de prosperidade dos países industrializados aumentaram a demanda de mercadorias brasileiras de exportação, provocando a alta dos preços". Assim, vários produtos tropicais, valorizados em todo o mundo, obtiveram sucesso e foram eles que impulsionaram a indústria brasileira. Dean (2002, p. 694) correlaciona: "foi o setor exportador que propiciou a demanda e o capital para as primeiras fábricas”. De modo geral, na análise comparativa do Brasil em relação à Argentina, Costa (200, p. 176) salienta que "embora fosse um país [...] tendo gozado de inserção no comércio mundial desde a primeira década da Independência, o Brasil teve, durante o período em estudo, um desempenho muito menos satisfatório".

No início do século XX, o país ainda passava por uma economia de "subsistência", formado por baixa produtividade do trabalho escravo no final do século XIX (Dean, 2002 pág. 660). Assim, formavam-se os ciclos econômicos que eram novas fontes de lucros, como o ciclo do algodão e do cacau no sul da Bahia e a cana-de-açúcar dos engenhos, responsáveis pela economia durante período colonial, conciliada à mão-de-obra indígena em parte, que gradualmente foi substituída pela mão-deobra escrava, até 1888, do Nordeste brasileiro. O Gráfico 1 demonstra a produção (em toneladas) de produtos primários selecionados entre 1901 e 1929. Segundo Dean (2002, p. 660), “o açúcar, apesar 
Artigo original

Hegemonia - Revista Eletrônica de Relações Internacionais do Centro Universitário Unieuro

ISSN: $1809-1261$

UNIEURO, Brasília, número 21, Julho-Dezembro de 2017, pp. 82-106.

do decréscimo em valor de suas exportações a partir do final do século XVII, manteve-se durante todo o período colonial como principal cultura comercial do Brasil”. E seguiu com destaque em quantidades produzidas, graças aos engenhos formados por fazendeiros que utilizaram a mão-de-obra escrava africana e/ou indígena e durante todo o período representou um dos momentos de maior desenvolvimento econômico do Brasil

Gráfico 1: Quantidade (tonelada) da produção dos principais produtos agrícolas: 1901-1929.

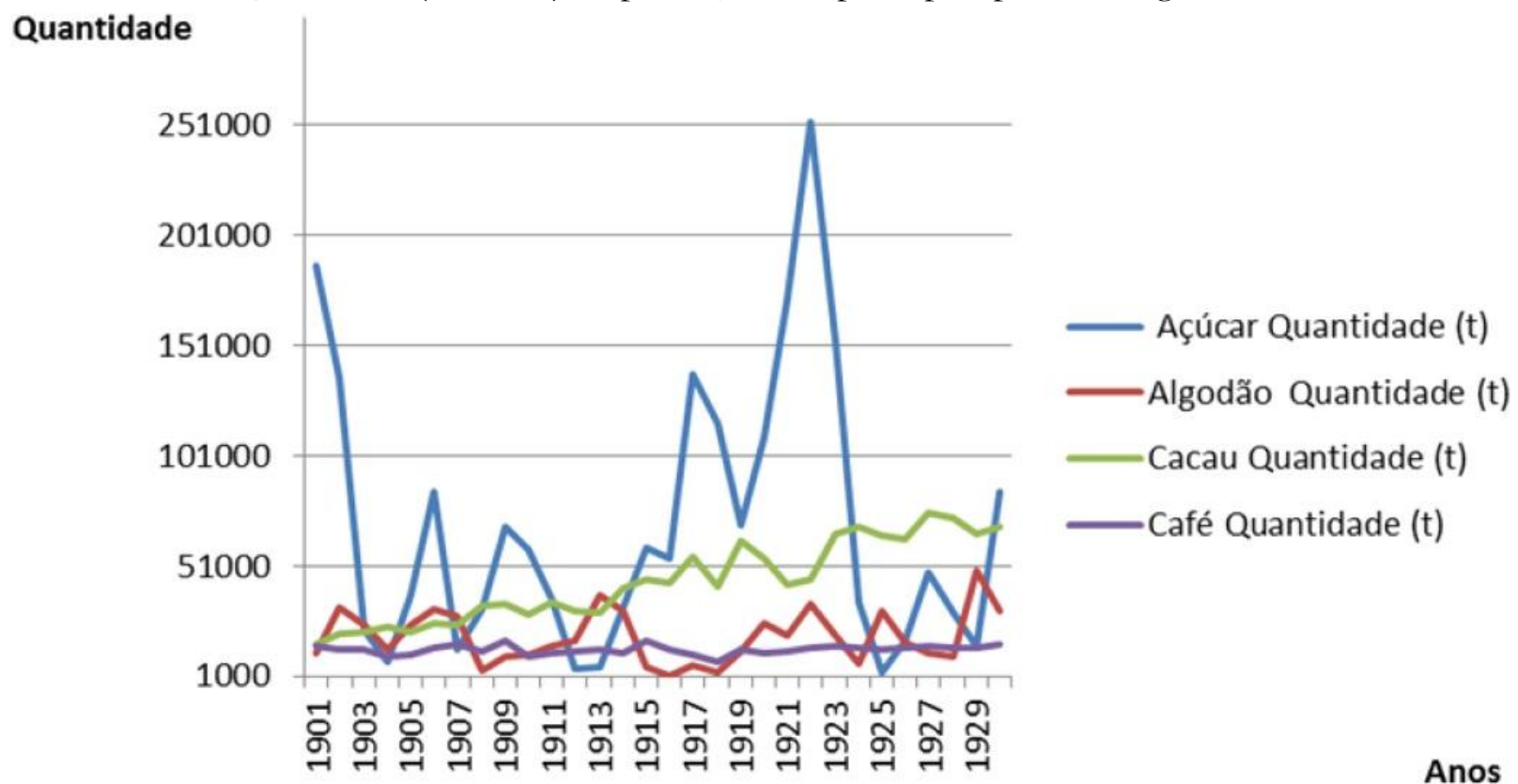

Fonte: Anuário Estatístico; fonte original: Serviço de Estatística Econômica e financeira, Ministério da Fazenda, (apud Baer, 1966, p. 285). 
Artigo original

Hegemonia - Revista Eletrônica de Relações Internacionais do Centro Universitário Unieuro

ISSN: $1809-1261$

UNIEURO, Brasília, número 21, Julho-Dezembro de 2017, pp. 82-106.

Conforme Gráfico 2, o café era o produto mais valorizado durante o período entre 1901 e 1929. Mais do que isso, outros produtos agrícolas, como o açúcar, o algodão e o cacau sequer se aproximação do valor do café após o final da segunda década do século XX. Todos esses produtos possuíam um papel muito inferior ao do café na pauta exportadora brasileira nesse período.

Gráfico 2: Valor (Cr \$ 1000) da quantidade produzida dos principais produtos agrícolas: 1901-1929. Valor (Cr \$ 1000)

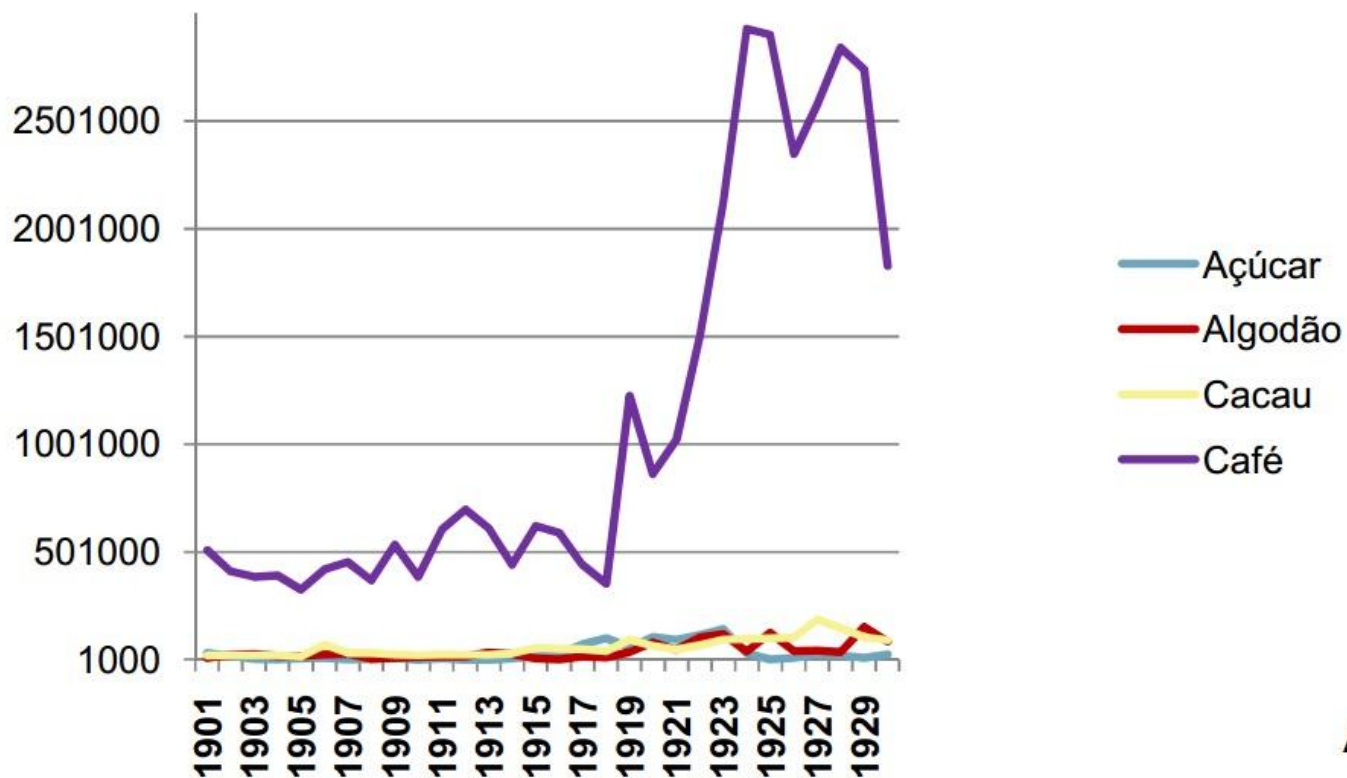

Anos

Fonte: Anuário Estatístico; fonte original: Serviço de Estatística Econômica e financeira, Ministério da Fazenda, (apud Baer, 1966, p. 285).

Sucessivamente, com grande expansão das exportações até aproximadamente 1913, a extração e comercialização da borracha do oeste da Amazônia, mostrou-se um fator importante na economia brasileira, com uma migração de nordestinos. Assim como o látex, havia outros produtos de natureza primária que influenciaram bastante a economia com destaques para o milho, o feijão, a banana, a farinha de mandioca, mate, couros, peles, dentre outros, que eram responsáveis pelo fluxo das exportações brasileiras deste primeiro período. As atividades mais importantes utilizavam materiais agrícolas locais como o próprio algodão, o couro, o açúcar, cereais, madeiras de construção e materiais não metálicos (barro, areia, cal e pedras).

O café se destacou como o principal produto da época, a partir de meados do século XIX até as primeiras décadas do século XX. Sendo assim, o café, a partir de 1910, impulsionou a expansão dos 
Artigo original

Hegemonia - Revista Eletrônica de Relações Internacionais do Centro Universitário Unieuro

ISSN: $1809-1261$

UNIEURO, Brasília, número 21, Julho-Dezembro de 2017, pp. 82-106.

negócios e retomou o crescimento das atividades e assim, a partir deste período destacou-se como o produto de maior rentabilidade no país. Conforme Fausto (2006, p. 75) “de 1910 a 1930, as vendas de café passaram a representar 50\% a 70\% dos lucros da exportação nacional'. Um dos fatores do dinamismo econômico que estabelecia com sucesso para o produto em destaque foi o favorecimento do impacto da crise exterior sobre a economia brasileira. Nesse sentido, de acordo com Furtado (2007, p. 251), "a oferta não brasileira atravessou uma etapa de dificuldades, sendo a produção asiática grandemente prejudicada por enfermidades que praticamente destruíram os cafezais da ilha de Ceilão”.

A análise ganha importância também porque pode revelar aspectos importantes da relação do Estado na economia, pois conseguia assim, uma situação privilegiada entre os produtos primários no comércio internacional, graças à defesa governamental. Fritsch (1990, p. 35), argumenta que a característica da economia primário-exportadora tinha sua vulnerabilidade descrita por dois tipos de choques exógenos, quais sejam, i) as flutuações da oferta do café, resultante deste efeito de variações climáticas sobre a produtividade dos cafezais e; ii) perturbações na economia internacional. De acordo com Furtado (2007) era inevitável que a oferta de café tendesse a crescer, pois com a vantagem relativa de exportação e a elasticidade da mão-de-obra livre, os cafeicultores estimulados com a inflação de crédito, passaram a amplificar suas terras. Essa abundância de terras influenciaria a baixa dos preços no longo prazo, que até o momento, com a depreciação cambial, encontravam-se elevados.

No final do século XIX, os cafeicultores brasileiros já controlavam três quartas partes da oferta mundial, conquanto Fristch (1990, p. 40) observa que o país ocupava uma posição de quase monopolista no mercado mundial. A busca de investimentos na economia formava juntamente com a retenção da oferta de café, pois neste período os preços se mantiveram elevados, favorecendo altas taxas de lucratividade, conforme Furtado (2007, p. 257).

3. A industrialização brasileira

A industrialização foi uma mudança secular profunda que implicava, entre outras coisas, o relativo declínio da atividade primária, uma rápida urbanização e a emergência do setor industrial (Lewis, 2001, p. 112). Durante muito tempo, a economia nacional concentrou-se nas importações da metrópole pelas regras da política mercantilista, assim não havia competição para prejudicar seus interesses comerciais, pois havia restrições para as atividades industriais. 
Artigo original

Hegemonia - Revista Eletrônica de Relações Internacionais do Centro Universitário Unieuro

ISSN: $1809-1261$

UNIEURO, Brasília, número 21, Julho-Dezembro de 2017, pp. 82-106.

No mundo ocorria uma disputa pelos mercados nacionais e internacionais, logo seguido da Primeira Revolução Industrial, registrada na Inglaterra no final do século XVIII e início do século XIX e, também, seguido da Segunda Revolução com o capitalismo financeiro. No Brasil, a política formulada da época privilegiava a agricultura e a urbanização se acentuava substancialmente, sendo que o rápido desenvolvimento da indústria de transformação ocorreu graças à imigração de trabalhadores, que se concentrava na parte sudeste do país em especial nas regiões específicas e causava o abandono de outras regiões. Isso, por sua vez, acarretava substancialmente desorganização de algumas regiões tradicionais.

Os componentes de formação de capital são evidenciados pela construção de portos e de estradas de ferro. Havia também as instalações de usinas de eletricidade, que antes eram formados por motores a vapor alimentados por carvão importados. Conforme Fausto (2006, p. 281) afirma, “o carvão tinha sido ingrediente importantíssimo da industrialização do século XIX, e a falta de carvão de boa qualidade era o obstáculo mais sério no tocante ao suprimento”.

O marco do crescimento das exportações dos produtos primários estabeleceu-se durante quase toda a totalidade do século XIX na economia do país. Ainda neste mesmo sentido, Fausto (2006, p. 283) afirma que "as técnicas mecânicas foram aplicadas no setor de exportação muito antes de quaisquer outras, [...] porque os seus produtos, tendo de competir no mercado internacional, precisavam ser eficientemente produzidos". Conforme o trecho em destaque:

O fabrico do açúcar, o acondicionamento da carne, o descaroçamento e o enfardamento do algodão, o curtume dos couros e o beneficiamento do café, portanto, figuravam entre as primeiras linhas de produção que seriam realizadas com vapor e energia elétrica. É interessante notar que no processamento do café descascar, separar, secar e classificar - não havia máquinas européias ou norteamericanas fabricadas com essas finalidades, e os inventores brasileiros criaram o seu próprio equipamento, acicatados pela escassez de escravos e, mais tarde, pela necessidade de poupar a mão-de-obra assalariada (Fausto, 2006, p. 283-284).

A indústria de ferro e de aço em grande escala só veio a experimentar um ligeiro desenvolvimento no último decênio do período. Segundo Dean (2002, p 667), “somente em 1905 foi iniciada a construção de uma estrada de ferro paralela ao rio, que não chegou a Belo Horizonte antes de 1930”. Também, segundo Fausto (2006, p. 278), “os cafeicultores de São Paulo, quase todos nativos investiam em estradas de ferro e docas, bancos e sociedades comerciais, necessárias à expansão dos seus negócios“. Nessas circunstâncias, Fausto (2006, p. 282) ainda salienta que "nos últimos 15 anos do Império, todavia, se assentaram alguns trilhos. Havia mais de 9.000 quilômetros por volta de 1889, aos quais se acrescentaram mais 17.000 nos primeiros 25 anos de República”. 
Artigo original

Hegemonia - Revista Eletrônica de Relações Internacionais do Centro Universitário Unieuro

ISSN: 1809-1261

UNIEURO, Brasília, número 21, Julho-Dezembro de 2017, pp. 82-106.

As indústrias vieram a surgir antes do século $\mathrm{XX}$, porém foram nas primeiras décadas do período que houve um desenvolvimento significativo, conjugado com o crescimento econômico do interior, que possibilitou o aumento de mercados consumidores para os manufaturados que começavam a ser fabricados no país. Conforme Loeb (apud Baer 1966) “de acordo com censo industrial de 1920, de 13.336 estabelecimentos existentes, somente 35 eram anteriores a 1850 e apenas 240 tinham sido fundada antes de 1880”.

Formava-se uma substituição do trabalho escravo para o trabalho assalariado e uma disponibilidade de mão-de-obra relativamente baixa. Com a imigração para as regiões mais ricas, como o sudeste do país, a população pecuária do Brasil concentrou-se na região do Rio Grande do Sul e Minas Gerais. Assim, formava-se um número relativamente grande de fazendeiros, que se beneficiavam dos armazéns, pois os imigrantes vinham produzir o café e consequentemente consumia os produtos dos armazéns de fazendeiros, que até 1920 só produziam artigos volumosos e de baixo valor, feitos com matérias-primas locais ou importadas.

Os trabalhadores ganhavam muito pouco, sendo que a maior parte do lucro pela produção do café ficava com os próprios fazendeiros. Como era uma fonte de lucro rentável, estes passaram a se dedicar aos produtos da indústria e do comércio. Logo, valorizava-se o comércio nacional e os fazendeiros elevavam o lucro empresarial do país.

No trecho de Furtado o termo ficou conhecido como fluxo de renda e crescimento:

Numa economia industrial a inversão faz crescer diretamente a renda da coletividade
em quantidade idêntica a ela mesma. Isto porque a inversão se transforma
automaticamente em pagamento a fatores da produção [...] A inversão feita numa
economia exportadora-escravista é fenômeno inteiramente diverso. Parte dela
transforma-se em pagamentos feitos no exterior [...]; a maior parte, sem embargo,
tem como origem a utilização mesma da força de trabalho escravo. Ora, a diferença
entre o custo de reposição e de manutenção dessa mão-de-obra e o valor do produto
do trabalho da mesma era lucro para o empresário. Sendo assim, a nova inversão
fazia crescer a renda real apenas no montante correspondente à criação de lucro para
o empresário. Esse incremento de renda não tinha, entretanto, expressão monetária,
pois não era objeto de nenhum pagamento (Furtado 2010, pág. 85).

Aos poucos o país sofria transformações, juntamente com o crescimento populacional que contribuía para a formação de uma enorme massa de imigrantes. Segundo Fausto (2006, p. 282), “os imigrantes, na grande maioria, eram jovens, preponderantemente do sexo masculino e, portanto, imediatamente produtivos" que possuíam técnica já utilizada dos países industrializados. Fausto (2006, p. 301) ainda enfatiza que "pertenciam quase todos às famílias da classe média e já tinham adquirido na Europa conhecimentos técnicos ou comerciais". 
Artigo original

Hegemonia - Revista Eletrônica de Relações Internacionais do Centro Universitário Unieuro

ISSN: 1809-1261

UNIEURO, Brasília, número 21, Julho-Dezembro de 2017, pp. 82-106.

Em 1900, o total da população residente chegava a aproximadamente 17 milhões de pessoas, população essa que formava a força de trabalho remunerada com baixos salários. Segundo Dean (2002, p. 681) “a imigração líquida para o Brasil, entre 1872 e 1930, alcançou o total de cerca de 2,2 milhões”, assim os próprios capitalistas, visando investimentos, resolveram dar início aos empreendimentos, muitos com pouco dinheiro, porém pouco diferidos das oficinas artesanais. A origem do capital industrial remonta ao período de expansão das exportações de café. Conforme Dean (2002, p. 662663), o empresário que se destacou nos anos 1850 e 1860 foi Irineu Evangelista de Souza agraciado com o título de Barão de Mauá, pelo fato de o governo ser um tanto hostil, queixou ter terminado sua carreira em falência.

Com interesse em defender somente a economia agrícola, os governos estaduais apelaram para o crédito internacional. As negociações continuaram e, por fim, um plano de refinanciamento de pagamentos é finalmente acordado entre o governo brasileiro e a casa Rothschild. Em 1898 e 1914, os ingleses concederam ao governo brasileiro um funding $\operatorname{loan}^{5}$, mas exigiram uma taxa de juros maior. O plano tratava de rolar os compromissos externos do governo brasileiro, vale dizer, o serviço da dívida pública externa e algumas garantias de juros, em troca de severas medidas de saneamento fiscal e monetário.

Da mesma forma, no final do século XIX, pode-se notar uma modernização da infraestrutura em toda América Latina. A indústria metalúrgica estava bem instalada no país, com a fundação de várias empresas no terceiro quarto do século. No Brasil e em outros países, era possível observar uma produção interna de produtos químicos (artigos farmacêuticos e matéria-prima industrial) (Lewis, 2001, p. 125). Assim, quando se formaram as condições para o desenvolvimento industrial (com o rompimento da estrutura agrária, a expansão do estoque de moeda e também as facilidades de crédito), aumentou-se o volume de investimento em novas fábricas e houve uma expansão das já existentes.

De grande importância se destaca o período no qual ocorreu a expansão de crédito como uma movimentação no mercado de títulos. Foi uma onda especulativa apelidada de encilhamento ${ }^{6}$ à política de emissão de dinheiro em grande quantidade que, conforme Stein (1979, pp. 97-99 e 104-105) apud Suzigan (1986), teve aspectos positivos ao estimular uma campanha em favor do apoio governamental à indústria de transformação, a qual resultou num empréstimo especial de 100000 contos para a indústria em 1982, e também em favor de maior proteção à indústria. Conforme explicação de Glade

\footnotetext{
${ }^{5}$ Funding loan: empréstimo para consolidar a dívida externa (Dean, 2002, p. 664).

${ }^{6}$ Encilhamento: período de intensa especulação seguido por uma grave crise no mercado de valores (Suzigan, 1986, p. 46).
} 
Artigo original

Hegemonia - Revista Eletrônica de Relações Internacionais do Centro Universitário Unieuro

ISSN: $1809-1261$

UNIEURO, Brasília, número 21, Julho-Dezembro de 2017, pp. 82-106.

(2001 pág. 696), "a indústria têxtil representava 40\% do capital investido nessas empresas, e o processamento de alimentos os outros 45\%". As fábricas, a exemplo das suas congêneres do setor de exportação, tinham grande porte físico, dominavam os bairros onde estavam localizadas e empregavam alguns dos processos mais modernos da época. De acordo com Fishlow (1972, p.13 apud Versiani), "o número de fábricas têxteis fundadas então e que ainda existiam em 1912 é muito menor que o correspondente a 1885-1894”.

O processo de industrialização do Brasil no período de 1900 pode ser interpretado como uma forma de substituição das importações. Conforme Fausto (2006, p. 298), os importadores nacionais "se viram na contingência de levar a efeito as operações de acabamento final dos bens que tinham importado". Assim, finalmente, possuíam condições para serem industriais, pois conheciam os consumidores, controlavam os canais de distribuição, tinham acesso ao crédito e sabiam o que importar e como distribuir os bens produzidos.

No início do século XX, o país vivia o regime republicano. O clima dos negócios era um pouco hostil ao empresariado capitalista, que antes atuava como fazendeiros ou importadores. Neste período algumas das fábricas intensivas de capital estavam produzindo para o mercado interno. De acordo com Furtado (2007 p. 323), “a primeira metade do século XX, está marcada pela progressiva emergência de um sistema cujo principal centro dinâmico é o mercado interno”. As fábricas eram pequenas empresas atípicas e na maioria dos casos eram pequenas oficinas primitivas e intensivas de trabalho que empregavam pequenos grupos de operários. A vantagem para os agricultores de café era que esses armazéns eram uma das fontes de lucros para o fazendeiro capitalista, que vendia a concessão ou a explorava (Lewis, 2001, p. 122).

A agricultura dominava o comércio, sobretudo, no que diz respeito à industrialização. Segundo Baer (1988), "a indústria contribuiu somente com 21\% do total dos produtos físicos em 1907 e 1919, comparados aos 79\% apresentados pela agricultura". Porém, isso beneficiou uma aceleração da indústria doméstica, que se utilizou de recursos que anteriormente atendia a esse comércio. Do mesmo modo que o café elevou a renda, seus lucros sustentaram empresas industriais fundadas por membros da elite nacional, numa época de instabilidade econômica dada por diversos choques externos a partir de 1914 (Fritsch, 1990, p. 31).

O crescimento da produção industrial foi realmente lento, segundo Baer (2009), “deveu-se somente, ao influxo de bens estrangeiros de melhor qualidade e preço numa economia dominada pelo 
Artigo original

Hegemonia - Revista Eletrônica de Relações Internacionais do Centro Universitário Unieuro

ISSN: 1809-1261

UNIEURO, Brasília, número 21, Julho-Dezembro de 2017, pp. 82-106.

setor agrícola". Havia se reduzido o estimulo para instalação de indústrias no Brasil, um país com uma economia em fase de crescimento. Como explica Furtado (2010, p. 279),

Outro fator que se deve ter em conta é a possibilidade que se apresentou de adquirir a preços muito baixos, no exterior, equipamentos de segunda mão. Algumas das indústrias de maior vulto instaladas no país, na depressão, o foram com equipamentos provenientes de fábricas que haviam fechado suas portas em países mais fundamente atingidos pela crise industrial.

Segundo Furtado (2007), “a industrialização teria de começar por aqueles produtos que já dispunham de um mercado de certa magnitude, como era o caso dos tecidos". Nessas circunstâncias, Lewis (2001, p. 122-123), observa que a indústria têxtil na América Latina, as vésperas da Primeira Guerra Mundial, estava bastante adiantada no Brasil, muitas empresas empregavam relativamente grande número de operários e atualizavam seu maquinário de fiação e tecelagem, assim expandia sua capacidade. De acordo com Versiani (1975), “em 1907, a produção de têxteis de algodão ultrapassou 300 milhões de metros, e seu valor era o dobro das importações dentro da mesma rubrica. Duas décadas antes [...] a produção fora avaliada em no máximo, 38 milhões de metros”. A produção da indústria têxtil algodoeira foi favorecida pelas grandes fábricas de tecidos, os dados podem ser vistos pela Tabela 1 abaixo.

Tabela 1: Produção da Indústria Têxtil Algodoeira no Brasil (1853-1932)

\begin{tabular}{ccc}
\hline Ano & $\mathrm{N}^{\circ}$. de fábricas & Operários \\
\hline 1853 & 8 & 424 \\
1866 & 9 & 795 \\
1855 & 48 & 3.172 \\
1905 & 110 & 39.159 \\
1915 & 240 & 82.257 \\
1921 & 242 & 108.960 \\
1925 & 257 & 114.561 \\
1929 & 359 & 123.470 \\
\hline 1932 & 355 & 115.550 \\
\hline
\end{tabular}

Fonte: Stanley Stein. The Brazilian cotton manufacture. Cambridge, Mass., Harvard University Press, 1957, p. 191, (apud Baer 2009).

Fausto (2006, p. 296) afirma que "as primeiras fábricas de fiação ás vezes produziam o fio para tecelões que trabalhavam em casa". As famílias eram as responsáveis pela unidade de produção, ainda Dean (2002, p. 692) apresenta uma tipologia clássica, no qual a substituição artesanal se tornou mais significativo para classificar este período:

Os produtos artesanais fabricados em casa destinavam-se ao próprio consumo da família e a venda ou troca, e os produzidos nas oficinas artesanais eram vendidos nos 
Artigo original

Hegemonia - Revista Eletrônica de Relações Internacionais do Centro Universitário Unieuro

ISSN: $1809-1261$

UNIEURO, Brasília, número 21, Julho-Dezembro de 2017, pp. 82-106.

mercados locais. Os tecidos de algodão e de lã, por exemplo, antes da instalação de fábricas têxteis, eram produzidos em grande parte pelas famílias. Quase toda casa de família e cubata de escravos tinha alguém que sabia fiar e tecer num tear a mão [...]. Em 1903, o Brasil consumiu aparentemente 1045 toneladas de linha de costura de algodão, todas importadas. No entanto, no mesmo ano, foram consumidas 21900 toneladas de roupas tecidas, nacionais e importadas.

Havia também os sindicatos, mas eram reprimidos pelo governo que fornecia grande proteção aos fazendeiros. Fausto (2006, p. 307) afirma que "havia no Brasil [...] várias centenas de sindicatos [...]. A sua oposição aos industriais limitava-se à greve, e as greves quase sempre ocorriam por atraso no pagamento dos salários e pelas despedidas em massa durante os períodos de recessão". Ainda Fausto (2006) enfatiza que, por pressões maiores de sindicatos que continuavam a surgir, poucas leis se promulgaram com a intensão de apaziguar a mão-de-obra como “o dia $1^{\circ}$ de maio passou a ser feriado, mas as limitações ao trabalho de mulheres e crianças, assim como as férias remuneradas, só se tornaram efetivas depois de 1930".

A historiografia observada em seus aspectos amplos analisa que o impacto da Primeira Guerra Mundial sobre a indústria brasileira tornou-se inteiramente favorável. Dean (1976, cap. 6 apud Suzigan) observa que "a interpretação dos fluxos normais de comércio exterior tenha sido benéfica para a indústria interna [...] e questiona se o desenvolvimento industrial não teria avançado mais se não tivesse ocorrido a guerra". Sendo assim, criaram-se durante a guerra, 5.936 novos estabelecimentos, e o valor da produção industrial cresceu de $212 \%$. Além disso, o recenseamento de 1919 revelou a existência de 13.336 estabelecimentos industriais que empregou um pouco menos de 300.000 trabalhadores. Estas situações e também após uma crise em 1893 nos EUA, os preços das exportações começaram a declinar, exatamente nessa época formava-se uma superprodução, uma observação era, com a acumulação da oferta do setor cafeeiro, tudo que necessitavam eram recursos financeiros para reter parte da produção fora do mercado, ou seja, contrair artificialmente a oferta, e mobilizar para quando a renda estivesse a altos níveis nos países importadores segundo Furtado (2007).

Em relação à produção interna, a taxa de câmbio favorecia até o momento. Conforme Fishlow (1972, pp. 12-13 apud Suzigan, 1986), o atraso na depreciação da taxa de câmbio em relação aos preços domésticos até meados de 1891, estimulou a importação de maquinaria industrial e a subsequente depreciação do mil-réis aumentou o preço relativo das importações. Isso, por sua vez, estimulava o crescimento industrial e o crescimento das exportações se tornaria uma especialização do setor cafeeiro. 
Artigo original

Hegemonia - Revista Eletrônica de Relações Internacionais do Centro Universitário Unieuro

ISSN: 1809-1261

UNIEURO, Brasília, número 21, Julho-Dezembro de 2017, pp. 82-106.

Além destas considerações, Furtado (2007, p. 278) ainda afirma que "não podia aumentar sua capacidade [...] sem importar equipamentos, e que estes se tinham feito mais caros com a depreciação do valor externo da moeda" ou mais precisamente a valorização da taxa de câmbio, assim formou-se o que Furtado (2007, p. 288-289) caracterizou como situação algo paradoxal, onde o Brasil fixava o valor externo da moeda e chegava a baixar o valor externo da moeda para recuperar o equilíbrio na balança de pagamentos. Nesse período, a taxa de câmbio favoreceu o processo industrial e se tornou importante para o sistema econômico. Segundo Dean (2002, p. 286), "a alta da taxa da cambial reduziu praticamente à metade o poder aquisitivo externo de moeda brasileira [...] permitirá um amplo barateamento relativo das mercadorias de produção interna”. No período da crise, conforme Baer (1966 p. 21), "o Brasil foi o primeiro país latino-americano a lançar mão do controle de câmbio e de outros controles diretos".

Esse controle por si encarecia o preço dos bens de capital importados, como cimento, aço maleável e várias espécies de máquinas. A partir disso, causava a queda das importações, o que ocasionou o mercado a tornar-se carente dessa indústria de base. Segundo Baer (1966, p. 22), "criavam-se, assim, incentivos para aumentar a produção interna das indústrias brasileiras que competiam com as importações [...] não demorou muito para [...] aplicar-se, direta ou indiretamente, em novas empresas industriais".

Conquanto houvesse interesses governamentais indisfarçáveis, conforme Leff (1982, apud Dean, 2002, p. 663) "os interesses de classe eram tão diversos que se podia duvidar seriamente da validade de usar a nação como a unidade de análise" e a sustentação do programa de "valorização" do café, financiada por consórcio internacional como metas do governo. Sendo assim, Furtado (2007, p. 256) interpreta que "o mecanismo de defesa da economia cafeeira era, em última instância, um processo de transferência para o futuro da solução de um problema que se tornaria cada vez mais grave”. Essa expansão substancial da indústria que ocorreu no estado de São Paulo também pode ser observada logo após o período de 1930. Então para manter o preço do café, principal produto de exportação, sempre em alta, formavam-se os acordos. Conforme Fausto (2006, p. 74), "elaborou-se em Taubaté, São Paulo, em 1906, um plano de três Estados, do qual participavam o Rio de Janeiro e Minas Gerais. Minas e Rio retiraram-se antes que o programa fosse posto em prática" e derivava naturalmente disto o acordo de Taubaté que consistia plenamente:

No convênio celebrado em Taubaté em fevereiro de 1906, definem-se as bases do que se chamaria política de "valorização" do produto. Em essência, essa política consistia no seguinte: a) com o fim de restabelecer o equilíbrio entre oferta e procura de café, o governo interviria no mercado para comprar os excedentes; b) o 
Artigo original

Hegemonia - Revista Eletrônica de Relações Internacionais do Centro Universitário Unieuro

ISSN: $1809-1261$

UNIEURO, Brasília, número 21, Julho-Dezembro de 2017, pp. 82-106.

financiamento dessas compras se faria com empréstimos estrangeiros; c) o serviço desses empréstimos seria coberto com um novo imposto cobrado em ouro sobre cada saca de café exportada; e d) a fim de solucionar o problema mais a longo prazo, os governos dos estados produtores deveriam desencorajar a expansão das plantações" (Furtado, 2007, p. 253-254).

Também houve a caixa de conversão, onde o governo compraria as divisas. Segundo Fritsch (1990, pág. 38) “em 1906, criou-se a Caixa de Conversão, investida do poder de emissão de notas plenamente conversíveis em ouro, e vice-versa, a uma taxa fixa de câmbio”, más somente para as notas de conversão, as outras não, e chegaria ao câmbio flutuante e juntamente a depreciação a taxa de câmbio era fixada num nível considerado. Em parte, financiada pelo capital oriundo do setor exportador em expansão.

O crescimento que se observou entre 1910 e 1914 deveram-se, também, à Caixa de Conversão “[...] que proporcionou maior saldo de divisas para a aquisição de maquinaria, instrumental e até matérias-primas para o desenvolvimento industrial”. Porém, com a Primeira Guerra Mundial, o governo fechou a caixa de Conversão e, conforme Fritsch (1990 pág. 41), "para tentar ganhar tempo com uma série de medidas de emergência".

Segundo estimativas de Goldsmith (1986, p. 82-83), o PIB real per capita a preços de 1910 se reduziu em cerca de 20\% entre 1890 e 1900, recuperando-se cerca de 35\% até 1913, com ganho acumulado de apenas 8,2\% entre 1890 e 1913. Em 1913, quando a população brasileira chegou a 24 milhões de habitantes, a situação econômica relativa do Brasil tinha se agravado. O PIB per capita brasileiro, segundo os mesmos critérios já mencionados, e a preços de 1990, passaria para US\$ 811 (depois de ter alcançado um mínimo de cerca de US\$ 678 em 1900, na esteira da estabilização do fim dos anos 1890).O período antes de 1930 foi uma fase de transição, uma passagem do capitalismo comercial para o industrial que se formava desde os séculos anteriores. Furtado (2007) relata que o desenvolvimento da indústria nos anos 30 tornou-se possível pela reação da economia e da política econômica ao desequilíbrio externo, que se seguiu à crise do café e à Depressão.

Assim, a atividade industrial veio desde os períodos antecedentes ao século XX, com efeito significativo. Houve indícios de que as décadas seguintes tenham sido uma fase de atividade investidora substancialmente inferior. Suzigan (1986, p. 45) afirma que "de fato, foi nesse período que estabeleceu grandes fábricas de tecidos e que outras indústrias começaram a se desenvolver" do qual teve maior crescimento na indústria de bens de consumo durável, especialmente a têxtil. No período da crise mundial, ocorreu uma rápida queda nos lucros dos fazendeiros que exportavam café, em 1915 foram 17.061 sacas por cr $\$ 620.490$ onde chegou ao topo do período de sacas vendidas, porém já em 
Artigo original

Hegemonia - Revista Eletrônica de Relações Internacionais do Centro Universitário Unieuro

ISSN: $1809-1261$

UNIEURO, Brasília, número 21, Julho-Dezembro de 2017, pp. 82-106.

1918 esse valor caiu para 7.433 sacas por cr \$ 352.727, isso logo após a Primeira Guerra Mundial que afetou vários setores agrícolas da economia brasileira, conforme Dean (p. 675) o café e a extração da borracha junto com a seda pura, tinham como destino principal os Estados Unidos que os importava com isenção de tarifas.

Sendo assim, a estrutura industrial do período analisado era dominada por indústrias leves, eram fábricas de tecidos, bebidas, calçados, chapéus e bengalas, vinagres azeite e óleo destinados alimentação, alimentícios, dentre outros produtos de fabricação básica. Os empresários produziam os bens de consumo mais simples e baratos, conforme Lewis (2001, p. 122) para atender a camada mais baixa havia a fabricação de sandálias de corda, sapatos baratos, nas décadas de 1900 e 1910, em vários países da América Latina houve mudanças técnicas também na fabricação de cerveja, em que foram investidas somas de capital e foram absorvidas rapidamente.

Como resultado disso, a Tabela 2, de Fuks (apud Baer 2003), demonstra a distribuição por setores da atividade industrial no período especificado entre 1920 e 1940 no Brasil.

Tabela 2: Distribuição por Setores da Atividade Industrial (Percentagens do valor total adicionado)

\begin{tabular}{ccc}
\hline Indústrias & 1920 & 1940 \\
\hline Minerais não metálicos & 4,7 & 5,3 \\
\hline Metalurgia & 4,3 & 7,7 \\
\hline Mecânica & 2,0 & 5,8 \\
\hline Madeira & 5,8 & 5,1 \\
\hline Diversos & 1,9 & 1,5 \\
\hline Papel e correlatos & 1,5 & 1,4 \\
\hline Artefatos de borracha & 0,2 & 0,7 \\
\hline Têxtil & 28,6 & 22,7 \\
\hline Vestuário, calçados e artefatos & 8,6 & 4,9 \\
de tecido & & 22,9 \\
\hline Produtos alimentares & 22,2 & 4,5 \\
\hline Bebidas & 5,9 & 2,2 \\
\hline Fumo & 3,9 & . \\
\hline
\end{tabular}

Fonte: Censos Industriais de 1920, 1940 e 1950. Preparado e tornando comparável (a preços correntes) por JAYMES FUKS, da Fundação Getúlio Vargas (apud Baer 2003).

Assim, o país ainda vivia a República Velha (1889-1930) ou Primeira República, o governo de São Paulo juntamente com Minas Gerais controlava o Executivo Federal. São Paulo era beneficiado pelo poder político, com a descentralização republicana que estimulava o comércio e mantinham os lucros no estado. No início não havia estímulos para a indústria de transformação, a oferta de dinheiro, 
Artigo original

Hegemonia - Revista Eletrônica de Relações Internacionais do Centro Universitário Unieuro

ISSN: 1809-1261

UNIEURO, Brasília, número 21, Julho-Dezembro de 2017, pp. 82-106.

era controlada por apenas um banco público e era orientado a conter a empresa privada. Com o passar dos tempos os bancos estrangeiros começaram a investir nas indústrias, os aventureiros chegavam atraídos pelo ganho fácil com as especulações financeiras na bolsa de valores e com as importações, no entanto, conforme Fausto (2006, p. 303) “os bancos geralmente preferiam os lucros mais elevados dos empréstimos comerciais e da especulação da moeda. Não havia um verdadeiro mercado para títulos e ações”.

De início, naturalmente, foram as exportações de café que deram a São Paulo a sua prosperidade, juntamente com Minas, que era o segundo maior produtor de café do Brasil, (Fausto, 2006, p. 70). O incentivo do governo aos negócios dava privilégios aos fazendeiros e comerciantes. Villela e Suzigan (pp. 78-79, 368, 371 apud Fausto, 2006, p. 80) observam que "o número de Estado dobrou entre os anos de 1933 e 1939; o valor da produção industrial triplicou no mesmo período. [...] por volta de 1939 o valor acrescentado pela indústria ao Estado igualou o da agricultura”. Dessa forma é de suma importante enfatizar que o estado também beneficiou a indústria de transformação, pois "havia isenção de taxas para a importação de matérias-primas e maquinário utilizado por empresas nacionais, que depois ficaram isentas" (Baer, 2009).

Conforme o Anuário Estatístico do Brasil (1971, pp. 515-16 apud Fausto 2006, p. 59), o estado de São Paulo “já ocupava uma posição de comando durante a República Velha e por ocasião do primeiro censo econômico em 1920, respondia por mais de dois sétimos da produção agrícola e industrial do Brasil”. E, conforme Lewis (2001, p. 122) destaca, “a cervejaria Antártica, em São Paulo, já se encontrava como umas das maiores empresas comerciais no país”. A instalação das indústrias de São Paulo teve sucesso desde o seu início, em relação ao crescimento industrial, teve maior concentração na capital, segundo a indústria paulista dependeu das exportações do café e foi graças ao café que formou esse desenvolvimento.

A indústria de São Paulo se destacou em relação às indústrias das demais regiões do país, conforme a economia monocultura, que influenciara esse desenvolvimento, tornava a cidade o centro de negócios de exportação e importação e das atividades, atraindo capitais estrangeiros e empresários. A crise no comércio mundial, caracterizada pela depressão de outubro de 1929, onde ocorreu uma queda continuada dos valores das ações da bolsa de Nova Iorque, ocasionada pela superprodução nos EUA, influenciou o comércio mundial e gerou a retirada dos capitais americanos no estrangeiro. Isso trouxe falência para os bancos e empresas nacionais, ruína das classes médias e desemprego aos trabalhadores. Furtado (p. 276 e 277), argumenta “[...] que de 1929 ao ponto mais abaixo da depressão 
Artigo original

Hegemonia - Revista Eletrônica de Relações Internacionais do Centro Universitário Unieuro

ISSN: 1809-1261

UNIEURO, Brasília, número 21, Julho-Dezembro de 2017, pp. 82-106.

a renda monetária no Brasil se reduziu entre 25 por cento". Assim, à medida que a guerra agravava a situação econômica mundial, o governo brasileiro se sentia forçado a adotar medidas para ajustar e tirar a economia da depressão.

Entre os anos de 1927 e 1929, as exportações brasileiras conseguiam absorver apenas duas terças partes da quantidade produzida. O desfecho foi uma oferta superior à demanda internacional. Furtado (2007, p. 258) relata que "para evitar essa tendência teria sido necessário que a política de defesa dos preços houvesse sido completada por outra de decidido desestímulo às inversões em plantações de café", pois a produção aumentava e as exportações mantinham-se estabilizadas. A produção máxima foi alcançada em 1933, no ponto mais baixo da depressão, resultado das plantações de 1927 e 1928. Nesse cenário, era impossível obter crédito no exterior para financiar a produção por causa da depressão no mercado internacional. Furtado (2007, p. 263-64) equacionou alguns pontos importantes sobre o que fazer e sobre quem iria pagar neste caso, o que mais convinha era:

Colher o café ou deixá-lo apodrecer nos arbustos, abandonando parte das plantações como uma fábrica cujas se fecham durante a crise? Caso se decidisse colher o café, que destino deveria dar-se ao mesmo? Forçar o mercado mundial retê-lo em estoques ou destruí-los? Caso decidisse estocar ou destruir o produto, como financiar essa operação?

Assim, sobre quem recairia a carga, caso fosse colhido o café? Um conjunto de circunstâncias leva a ver que o problema técnico conceitual era o que fazer e quem pagar. Além disso, a renda poderia ser gerada em dois setores: setor de subsistência e no setor de atividades de exportação. $O$ importante era observar que o valor do produto que se destruía era inferior ao montante da renda que se criava. Com as políticas de retenção e destruição de parte da produção cafeeira e com o objetivo de proteger o setor cafeicultor, o nível de emprego foi garantido com preços mínimos de compra. Assim, se questiona o erro básico no período de acúmulo de café, que caracterizava a economia brasileira desde o princípio do século. Furtado (2007, p. 258) afirma, "o erro, se assim podemos qualificar, estava em não se terem em conta as características próprias de uma atividade econômica de natureza tipicamente colonial, como era a produção de café no Brasil”.

Ocorreu no Brasil uma política anticíclica precisamente para defender determinados setores. Furtado afirma que, em 1933 já iniciava o crescimento da renda nacional no Brasil, mais adiantado que nos EUA, sem haver também nos 
Artigo original

Hegemonia - Revista Eletrônica de Relações Internacionais do Centro Universitário Unieuro

ISSN: 1809-1261

UNIEURO, Brasília, número 21, Julho-Dezembro de 2017, pp. 82-106.

períodos de crise inversões líquidas negativas. Isso se deve somente à política de fomento, enquanto que o rápido aumento nos meios de pagamentos não poderia deixar de refletir no mercado cambial. Sem embargo, de acordo com Dean (2002, p. 663), para ajudar os fazendeiros que tinham sofrido a perda de seus escravos no final do império, foram lançados títulos do governo. Assim como Fritsch (1990) afirma, as dificuldades com a safra de café tornou necessária a emissão de títulos por parte do Banco do Brasil.

Para Furtado (2010, p. 286), a questão cambial ocupou um papel decisivo, sendo que, com o mecanismo de desvalorização cambial, os importadores nunca poderiam estar certos de qual seria o valor da taxa cambial que teriam de liquidar determinada transação. O objetivo era ampliar as receitas do governo, porém houve efeitos colaterais que resultou na criação das empresas têxteis. Uma recuperação compreendida entre 1934 e 1935 elevou os preços dos produtos primários, enquanto que a grande elevação da renda real per capita nos EUA nos anos 20 deixou inalterável o consumo nesse país, chegava então ao problema da demanda. Furtado (2007, p. 267), afirma que nos anos de depressão os preços chegaram a baixar cerca de quarenta por cento: "houve assim dois efeitos positivos no sentido do aumento do consumo: elevação de renda real per capita e baixa de preço".

Da mesma maneira, por outro lado, Fausto (2006, p. 309) afirma que o ritmo diminuiu depois de 1914, pois "assinalou a destruição do mercado livre do mundo em artigos de comércio, capital e trabalho". Neste sentido, a produção, durante a Primeira Guerra Mundial, foi limitada pela escassez de matérias-primas e insumos importados até o final da guerra, porque não havia no país produção interna de máquinas industriais, essas importações dominava a economia brasileira, que recaiu sobre o investimento industrial, más veio a recuperar-se nos anos posteriores consequentemente alguns fatores importados foram substituídos por insumos domésticos.

$\mathrm{Na}$ verdade, o principal impacto da guerra para o comércio exterior brasileiro foi a estagnação das importações, que afetaram o equilíbrio fiscal do governo (uma vez que as tarifas de importação constituíam um importante meio de receitas governamentais). A partir disso, Fritsch (1990, p. 71) também caracteriza esse 
Artigo original

Hegemonia - Revista Eletrônica de Relações Internacionais do Centro Universitário Unieuro

ISSN: 1809-1261

UNIEURO, Brasília, número 21, Julho-Dezembro de 2017, pp. 82-106.

primeiro período como "o dramático desequilíbrio externo sofrido pelo Brasil a partir do fim dos anos 20 em decorrência do colapso dos mercados internacionais de capital [...] alterou completamente as condições de viabilidade [...] da economia brasileira”. Além disso, a relação entre os movimentos de capitais e a evolução da capacidade para importar informa sobre a influência daquele sobre $\mathrm{O}$ estado das contas externas do país e, consequentemente, sobre as flutuações da taxa de câmbio.

Segundo Fausto (2006), a frase: “a Primeira Grande Guerra como grande estímulo para a industrialização, trata-se de uma impressão errônea, pois as fábricas locais não possuíam estruturas suficientes para compensar as importações e não usufruíam de aparelhamento para produzir artigos desaparecidos. Sendo assim, essa estrutura formava a industrialização das três primeiras décadas do século XX. Segundo Dean (2002, p. 659), o "período que representa o apogeu para as exportações" e constitui o início de um período industrial formada pelas indústrias leves, vindo de um setor exportador agrícola, uma substituição de importações de artigos industrializados que gerou uma ampla formação econômica. Por fim, tendo em vista este cenário, o governo traçou sua política econômica, permitindo que o período da República Velha sobrevivesse até a revolução de 1930 quando Getúlio Vargas, o verdadeiro gestor da indústria no país, toma o poder e permanece durante 15 anos. Apesar dessas dificuldades, comparado com outros países da América Latina, o Brasil nos períodos pós e durante as crises teve grandes avanços em relação aos outros países.

\section{Considerações finais}

A industrialização no Brasil nas primeiras décadas do século XX foi estabelecida por transformações na estrutura econômica e mudanças sociais, formado pelo crescimento da massa populacional e constituído por imigrantes que era formado por uma força de mão-de-obra barata assalariada e a importação de tecnologia dos países industrializados. 
Artigo original

Hegemonia - Revista Eletrônica de Relações Internacionais do Centro Universitário Unieuro

ISSN: 1809-1261

UNIEURO, Brasília, número 21, Julho-Dezembro de 2017, pp. 82-106.

A economia era voltada para as exportações dos produtos agrícolas, onde a demanda internacional formaram os antecedentes do desenvolvimento industrial. Diversos ciclos obtiveram sucesso graças as condições globais do país, como o do açúcar, do cacau, da borracha e do café, sendo este último o mais longo dos ciclos.

Do mesmo modo, as importações eram constituídas por artigos manufaturados, máquinas e equipamentos que desde então não eram fabricados nacionalmente. $O$ nível de investimentos tendia a crescer, pois acompanhava o ciclo do café, que representava uma situação privilegiada no mercado internacional. Sendo assim, este período foi também constituído por guerras e crises como a Primeira Guerra Mundial e a crise de 1929, no final do período, assim ocorriam o declínio no mercado internacional, no mesmo sentido a análise pode ocorrer se isso favoreceu ou não o processo industrial. $O$ desequilíbrio externo era substancialmente a mudança do capitalismo comercial para o industrial, conforme Lewis (2001, p. 173) afirma "a crise do setor externo inverteu o aumento da renda e corroeu os recursos disponíveis para a indústria”.

Se por um lado as crises declinavam as exportações, por outro lado ficava mais difícil importar, pois os países não se encontravam em condições de fornecer os produtos importados. Com isso, o que veio a causar substancialmente o processo industrial garantia uma ligação direta, que partia de um termo caracteristicamente usado por Baer (1988) "ISI", uma substituição das importações e conjuntamente a decadência das exportações dos produtos agrícolas. Neste sentido, os próprios importadores, que possuíam os conhecimentos necessários, começaram a produzir nacionalmente, formando assim, uma indústria de base. No início, constituía-se por bens leves, como os têxteis, para atender a camada mais baixa produzidos pelos empresários como bens de consumo mais simples e baratos, que antes eram fabricados nas próprias casas de tecelões e bebidas.

O governo, caracterizado como República Velha ou Primeira República, com a descentralização republicana, beneficiou São Paulo através do poder político que tinha determinadas preocupações com a economia. A indústria paulista dependeu das exportações do café e foi graças as exportações que formou esse desenvolvimento, assim é de relevada importância à análise do café durante todo o 
Artigo original

Hegemonia - Revista Eletrônica de Relações Internacionais do Centro Universitário Unieuro

ISSN: 1809-1261

UNIEURO, Brasília, número 21, Julho-Dezembro de 2017, pp. 82-106.

período, pois existiam os interesses governamentais e constituíram vários acordos como a compra dos excedentes e outros investimentos a favor. Desta forma, prevalecia um conjunto mais amplo de interesses para restabelecer a estabilidade econômico-financeira. Porém, foi logo depois da crise de 1930, que se destaca a maior taxa de crescimento da produção industrial, e que veio desenvolver o processo industrial no Brasil. Desde então, se confirma que os períodos de crise foram relativamente favoráveis para o crescimento da indústria no país.

Por fim, O período de estudo constatou a implantação de mais uma forma de concentração da renda através das imigrações de regiões composta pela mobilidade social e também formado por incentivos internos ao crescimento, no qual, a economia se favoreceu e diversificou rapidamente durante as três primeiras décadas do século XX.

5. Referências bibliográficas

ABREU, Marcelo Paiva. 1990. Crise, Crescimento e Modernização Autoritária: 1930 - 1945. In ABREU, Marcelo Paiva Org. A Ordem do Progresso: cem anos de política econômica republicana -1889 a 1989. Rio de Janeiro. Editora Campus, p.73-104.

BAER, Werner. 1966. A Industrialização e o Desenvolvimento do Brasil. Rio de Janeiro: Editora Fundação Getúlio Vargas, $7^{\text {a }}$ Edição.

BAER, Werner. 2009. A Industrialização e o Desenvolvimento Econômico do Brasil. Rio de Janeiro: Editora Fundação Getúlio Vargas, $1^{\text {a }}$ Edição.

BULMER-THOMAS, Victor. 2005. As Economias Latino-Americanas, 1929-1939. In BETHEL, Leslie Org. História da América Latina após 1930. São Paulo: Editora da Universidade de São Paulo/Imprensa Oficial do Estado; Brasília: Fundação Alexandre Gusmão, volume VI, p.19-76.

COSTA, W. P. (2000). Economia primário-exportadora e padrões de construção do Estado na Argentina e no Brasil. Campinas: Economia e Sociedade (14): 175-202. 
Artigo original

Hegemonia - Revista Eletrônica de Relações Internacionais do Centro Universitário Unieuro

ISSN: 1809-1261

UNIEURO, Brasília, número 21, Julho-Dezembro de 2017, pp. 82-106.

DEAN, Waren. 2002. A Economia Brasileira, 1870-1930. In BETHEL, Leslie Org. História da América Latina. São Paulo: Editora da Universidade de São Paulo/Imprensa Oficial do Estado; Brasília: Fundação Alexandre Gusmão, volume V, p. 659-704.

FAUSTO, Boris (Dir.). História geral da civilização brasileira: o Brasil republicano. V.8,3: Estrutura de poder e economia. 8. Ed. Rio de Janeiro: Bertrand, 2006.

FRITSCH, Winston. 1990. Apogeu e Crise na Primeira República. In ABREU, Marcelo Paiva Org. A Ordem do Progresso: cem anos de política econômica republicana -1889 a 1989. Rio de Janeiro. Editora Campus, p.31-72. FURTADO, Celso. 2007. Formação Econômica do Brasil. Rio de Janeiro: Companhia das Letras.

GLADE, Willian. 2001. A América Latina e a Economia Internacional, 1870-1914. In BETHEL, Leslie Org. História da América Latina. São Paulo: Editora da Universidade de São Paulo/Imprensa Oficial do Estado; Brasília: Fundação Alexandre Gusmão, volume IV, p.21-82.

GOLDSMITH, R., Brasil 1850-1984. Desenvolvimento Financeiro sob um Século de inflação, Haper \& Row, 1986.

IBGE. 1986. Séries estatísticas retrospectivas. Fundação Instituto de Geografia e Estatística. Rio de Janeiro, volume 1.

LEWIS, Colin M. 2001. A indústria na América Latina antes de 1930. In BETHEL, Leslie Org. História da América Latina. São Paulo: Editora da Universidade de São Paulo/Imprensa Oficial do Estado; Brasília: Fundação Alexandre Gusmão, volume IV, p. 111-174.

SUZIGAN, Wilson. Indústria brasileira: origem e desenvolvimento. São Paulo: Brasiliense, 1986. P. 45-73.

THORP, Rosemary. 2001. A América Latina e a Economia Internacional, da Primeira Guerra Mundial à Grande Depressão. In BETHEL, Lelie Org. História da América Latina. São Paulo: Editora da Universidade de São Paulo/Imprensa Oficial do Estado; Brasília: Fundação Alexandre Gusmão, volume IV, p. 83-110. 
Artigo original

Hegemonia - Revista Eletrônica de Relações Internacionais do Centro Universitário Unieuro ISSN: 1809-1261

UNIEURO, Brasília, número 21, Julho-Dezembro de 2017, pp. 82-106.

VERSIANI, F.R. \& VERSIANI, M.T. a Industrialização brasileira antes de 1930: uma contribuição. In: Estudos Econômicos, vol. 5, n. 1, 1975. 